
CONTEXT

\author{
Stela Karaj \\ University of Tirana, Albania \\ E-mail: stelaka@yahoo.com \\ Elida Rapti \\ University of Arts, Albania \\ E-mail: elidarapti@yahoo.com
}

\begin{abstract}
The purpose of this study was to determine the impact of the students'disruptive behavior and other factors in the school context on the teachers'job stress. For this purpose a survey based descriptive research was conducted with 540 basic education teachers. The instrument used was a structured questionnaire which was comprised of four scales for measuring teacher stress, students' disruptive behavior, time pressure and workload, relations with school principal and relations with colleagues. Pearson product-moment correlation coefficient was used to determine the direction and the strength of the relationships between the teachers' job stress and the stress related factors. Standard multiple regression was used to determine the amount of variability on teachers' job stress explained by the independent factors involved in the study.

The study findings indicated low to substantial correlations between teachers' job stress, students' disruptive behaviour, time pressure and workload, relations with school principal and relations with colleagues. Students'disruptive behaviour, time pressure and workload and relations with school principal were found to be significant predictors of teachers' job stress. Relations with colleagues were not found to be a significant predictor of teacher stress.
\end{abstract}

Key words: relation with colleagues, relation with school principal, students'disruptive behavior, teacher job stress, time pressure and workload.

\title{
Introduction
}

Starting from the early 1970s teacher stress has developed progressively and has become a major topic of international interest (Kyriacou, 2001). Teaching has widely and frequently been identified as a stressful profession (Guthrie, 2006; Kyriacou \& Chien, 2004; Lambert \& McCarthy, 2006; Betoret, 2006, Antoniou, Polychroni, and Vlachakis, 2006; Schwarzer and Hallum, 2008; Zedan, 2012). According to Jesus and Conboy (2001) it is common for teachers to experience higher stress levels than other professional groups.

In general, stress can be defined as "a process of behavioral, emotional, mental, and physical reactions caused by prolonged, increasing or new pressures which are significantly 
greater than coping resources' (Dunham, 1992, p. 3). Stress might have positive and negative effects (Lazarus \& Folkman, 1984). Stress at the optimal level (eustress) has the effect of mo-

PROBLEMS

OF EDUCATION

IN THE $21^{\text {st }}$ CENTURY

Volume 54, 2013

tivating (Nydegger, 2002). However, despite the fact that response to stress might also be positive for many researchers the discussion and the definition of the teacher stress focuses almost exclusively on its negative reactions. (Wilson, 2002). Consistent with this standpoint Kyriacou (2001) defines teachers stress as an experience by teachers of negative feelings like anger, anxiety, tension, frustration, depression which are caused by different aspect in the teacher's job.

Numerous studies conducted with elementary and secondary school teachers have shown the time pressure and work overload to be one of the most stressful aspects of teachers' job (Kyriacou \& Sutcliffe, 1978; Kyriacou, 2001; Thomas, Clarke \& Lavery, 2003; Boyle, Borg, Falzon \& Baglioni, 1997; Pithers \& Soden, 1998; Abel \& Sewell, 1999; Kokkinos, 2007; Kokkinos, Panayiotou, \& Davazoglou, 2005; Zedan, 2012).

There is also a widespread consensus among researchers that students' disruptive behavior is among the most important sources of teacher stress. (Payne Furnham, 1987; Borg and Riding, 1991; Borg, Riding, and Falzon, 1991; Byrne, 1994; Abel \& Sewell, 1999; Friedman, 1995; Kokkinos, 2007; Antoniou, Polychroni \&Vlachakis, 2006; Geving, 2007; Kyriacou \& Sutcliffe, 1978; Otero-López, Santiago, Godás, Castro, Villardefrancos \& Ponte, 2008; Grayson \& Alvarez, 2008; Evers, Tomic, \& Brouwers, 2004; Zedan , 2012)

Other significant potential stressors for teachers are: lack of support from the principals (Blase, Blase, \& Du, 2008; Grayson \& Alvarez, 2008); poor relations with colleagues (O'Connor \& Clarke, 1990; Driscoll \& Beehr, 2000; Kokkinos 2007); low social status and low salaries (Chaplain, 2001); role ambiguity and conflicting job roles (Kokkinos, 2007); lack of esteem by society (Grayson \& Alvarez, 2008); lack of participation in decision making process (Manthei \& Gilmore, 1996); poor physical working conditions (McCormick, 1997; Kokkinos, 2007).

Teacher stress has been linked to a numerous negative consequences ranging from burnout (McCarthy, Lambert, O'Donnell, \& Melendres, 2009); reduced job satisfaction (DeNobile \& McCormick, 2007); poor job performance and poor job commitment (De Nobile \& McCormick, 2007; Jepson \& Forrest, 2006) and leaving the profession (Ingersoll \& Smith, 2003). Under these conditions studying stress experienced by teachers and school principals occurs to be a primary issue.

Stress in teaching is widespread for both developed and developing countries and Albanian teachers are not immune to this phenomenon. Compared to other countries where many stress related studies are carried out, in Albania this field seems to be totally unexplored. This is one reason that makes it necessary to study the stress of teachers in the Albanian context. Another important reasons that necessitate the conduction of such research in the Albanian context is connected with the potential differences in the main sources of teacher stress due to variation between countries and national education systems (Kyriacou, 2001).

The purpose of the present study is to identify the direction and the strength of the correlations between teachers' job stress, students' disruptive behavior, time pressure \& workload, relations with colleagues and relations with school principal in the Albanian school context. This study also aims especially at determining the impact of students' disruptive behavior in teachers job stress compared to three sources which have been proved as important ones in various teachers stress related studies: time pressure \& workload, relations with colleagues and relations with school principal. 
Stela KARAJ, Elida RAPTI. Teacher Job Stress in Albania: Examining the Role of Students' Classroom Disruptive Behavior and Other Factors in the School Context

\author{
PROBLEMS \\ OF EDUCATION \\ IN THE $21^{\text {st }}$ CENTURY \\ Volume 54, 2013 \\ 16 Methodology of Research
}

Sample of Research

The population in this study consisted of $30.567^{1}$ basic education teachers in Albania. Out of this population were randomly selected 540 teachers in 25 basic education schools in 5 districts. Out of these counties were randomly selected five schools (3 elementary schools and 2 secondary) and interviews were later made to all the teachers of these schools. The questionnaire completion from the teachers was made following their teaching classes at working place beyond the presence of interviewers. Considering that the sample is heterogeneous to its characteristics it provides $\pm 5 \%$ sampling error (Yamane, 1967).

\section{Instruments and Procedures}

The instrument in this study was a structured questionnaire. In the first part are included questions pertaining to the demographic characteristics of teachers. In the second part are included a scale for the measurement of job stress adapted by Crank, Regoli, Hewitt and Culbertson (1995), three scales for the measurement of students' disruptive behavior, relations with colleagues and relations with school principal adopted by Skaalvik \& Skaalvik (2011) and a scale for the measurement of time pressure and work overload with items adapted from Skaalvik \& Skaalvik (2011) and Osipov (1998).

The scale for measuring job stress was composed of these items: "A lot of time my job makes me very frustrated or angry"; "I am usually under a lot of pressure when I am at work"; "When I am at work I often feel tense or uptight; "I am usually calm and at easy when I am working".

The scale for students' disruptive behavior comprised the following items: "My teaching is often disrupted by students who lack discipline"; "The lesson at my class is often interrupted by undisciplined students"; 'Some students with behavioral problems make it difficult to carry out lessons as I planned"; "Controlling students' behavior takes a lot of time and effort".

Time pressure and workload was measured by the following items: "'I think that I have a great deal of work to do'; In my job I need to do different tasks within a short period of time'; 'In my job as a teacher the acquirements are increasing thus I need to work fast to accomplish them'; 'I do more than I should normally as a teacher do'; ' I am charged to do tasks at school such as (assignment checking, fill in forms, statistics etc.) under very strict deadlines"; "Life at school is hectic and there is no time for rest and recovery"

The scale for the measurement of the relations of teachers with the school principal comprised these items: 'I can always ask for help and advices in issues related to teaching from the school principal"; "My relations with the school principal is one of mutual trust and respect";"The school leadership is supportive and praises good work".

Teachers' relations with their colleagues were measured by the following items: "My colleagues always help me when I need them in issues related to teaching"; "The relations among colleagues at this school are characterized by friendliness and a concern from each other"; "Teachers at this school help and support each other"

All the scales were translated to Albanian by two free lance translators. The scales were later adopted into Albanian language and were then translated into English back again by native English speakers in order to guarantee they complied with the original scales in English. The factorial analysis confirmed the one dimensional nature of each scale.

To evaluate the internal consistency of each scale was used the Cronbach 'Alfa coefficient (Cronbach, 1951). The reliability coefficient for each scale in the sample of this study was: job stress with four items $(\alpha=0.67)$; time pressure and workload with 6 items $(\alpha=0.72)$; relations

1 Source: Albanian Ministry of Education, 2012. 
with colleagues with three items $(\alpha=-0.72)$; relations with the school principal with three items $(\alpha=-0.66)$; and students' disruptive behavior with three items $(\alpha=0.77)$. As it can be seen only the scales for the work stress measurement and relations with the school principal had a acceptable reliability coefficient, while the coefficients for all the other scales were good $(\geq 0.7)$.

\section{Data Collection and Data Analysis}

The data collection for this study took place during the school year 2012-2013. Data analysis was carried out using SPSS. Pearson product-moment correlation coefficient was used to determine the direction and the strength of the relationships between the teachers' stress and the stress related factors. The description of correlation coefficients was made based on the Davis's descriptors (1971). To determine at what extent the four factors predict the overall stress job was used the multiple linear regression. Before the regression was processed verification was made in relation to check if the assumptions were met for this analysis. The examination of the matrix of the inter correlations between independent variables (time pressure \& workload, students' disruptive behavior, relations with school principals and relations with colleagues) and the dependent variable (stress of teachers at work) showed that the relations are linear. Likewise the verification of correlations among the independent variables showed that the problem of multicolinearity does not exist. The correlation coefficients among the independent variables were weak to moderate (Davis, 1971). (See table 1). The examination of the plots of the residuals indicated that the distribution of residuals was normal and the variance was homogeneous. Durbin Watson test statistics of 1.72 reveals that autocorrelation is not an issue.

\section{Results of Research}

The correlation' coefficients between the teachers' stress and the stress related factors are presented in Table 1.

Table 1. Correlations between teacher' job stress and independent variables.

\begin{tabular}{llllll}
\hline & $\mathbf{1}$ & $\mathbf{2}$ & $\mathbf{3}$ & $\mathbf{4}$ & $\mathbf{5}$ \\
\hline Teacher' job stress & 1 & & & & \\
\hline Relations with school principal & $-0.307^{* *}$ & 1 & & & \\
\hline Relations with colleagues & $-0.238^{* *}$ & $0.467^{* *}$ & 1 & & \\
\hline Time pressure \& Work overload & $0.349^{* *}$ & $-0.101^{* *}$ & $-0.170^{* *}$ & 1 & \\
\hline Students' disruptive behavior & $0.583^{* *}$ & $-0.224^{* *}$ & $-0.139^{* *}$ & $0.400^{* *}$ & 1 \\
\hline${ }^{*}$. Correlation is significant at 0.05 level & & & & & \\
(2-tailed). & & & & & \\
**. Correlation is significant at the 0.01 level \\
(2-tailed).
\end{tabular}

Correlations vary from low to substantial. The correlation between the relations with school principal and teacher's job stress is negative, moderate and significant $(\mathrm{r}=-0.307, \mathrm{p}<$ 0.01 ). The correlation between teacher's stress and relations with colleagues is low and negative, but significant $(\mathrm{r}=-0.238, \mathrm{p}<0.01)$. The correlation between time pressure \& work overload and teacher stress is moderate, positive and significant $(\mathrm{r}=0.349, \mathrm{p}<0.01)$. Meanwhile, the correlation between students' disruptive behavior and teachers 'stress is substantial, positive and significant $(\mathrm{r}=0.583, \mathrm{p}<0.01$ (see Table 1$)$. 
Stela KARAJ, Elida RAPTI. Teacher Job Stress in Albania: Examining the Role of Students' Classroom Disruptive Behavior and Other Factors in the School Context

OF EDUCAT

IN THE $21^{\text {st }}$ CENTURY

Volume 54, 2013

Table 2. Prediction of teachers' job stress at work by students' disruptive behavior, relations with school principal, time pressure \& work overload and relations with colleagues.

\begin{tabular}{|c|c|c|c|c|c|}
\hline $\mathbf{R}$ & R Square & $\begin{array}{l}\text { Adjusted R } \\
\text { Square }\end{array}$ & $\begin{array}{l}\text { Standard Error of the } \\
\text { estimate }\end{array}$ & $\mathbf{F}$ & Sig. \\
\hline \multirow[t]{3}{*}{$0.647^{a}$} & 0.419 & 0.414 & 2.98140 & 79.461 & $0.000^{\mathrm{a}}$ \\
\hline & \multicolumn{2}{|c|}{ Unstandardized Coefficients } & \multicolumn{2}{|l|}{ Standardized coefficients } & \\
\hline & B & $\begin{array}{l}\text { Standard } \\
\text { deviation }\end{array}$ & Beta & $\mathrm{t}$ & Sig. (p value) \\
\hline (Constant) & 8.422 & 1.180 & & 7.140 & 0.000 \\
\hline $\begin{array}{l}\text { 1. Time pressure and } \\
\text { workload }\end{array}$ & 0.079 & 0.031 & 0.102 & 2.550 & 0.011 \\
\hline $\begin{array}{l}\text { 2. Relations with col- } \\
\text { leagues }\end{array}$ & -0.113 & 0.059 & -0.080 & -1.923 & 0.055 \\
\hline $\begin{array}{l}\text { 3. Relations with school } \\
\text { principal }\end{array}$ & -0.241 & 0.063 & -0.160 & -3.840 & 0.000 \\
\hline $\begin{array}{l}\text { 4. Students' disruptive } \\
\text { behavior }\end{array}$ & 0.531 & 0.042 & 0.515 & 12.709 & 0.000 \\
\hline
\end{tabular}

a. Dependent Variable : teachers' job stress

A standard multiple regression analysis was carried out to determine the extent to which teachers' job stress was predicted by the independent variables (time pressure \& work overload, students' disruptive behavior, relations with school principal and relations with colleagues). The results are significant because independent variables explain about $42 \%$ of the variability in the dependent variable $\left(\mathrm{R}^{2}=0.419, \mathrm{~F}(4,441)=79.46, \mathrm{p}<0.001\right)$. Furthermore, the overall correlation displays a significant figure $(\mathrm{R}=0.647)$. Excluding the relations with colleagues which has a value $p=0.055$, that is slightly higher than the accepted value of $p(\beta=-0.080, p>0.05)$, all the other independent variables are significant predictors of teachers' job stress: students' disruptive behavior $(\beta=0.531, p<0.001)$, relations with school principal $(\beta=-0.160, p<0.001)$ and time pressure $\&$ work overload $(\beta=0.102, p<0.001)$ (see Table 2 ).

\section{Discussion}

The findings in this study proved that there are significant correlations between teachers' job stress and the four variables included in the study students' disruptive behavior relations with school principal, time pressure \& work overload and relations with colleagues. The strongest correlation was that between teachers' stress and students' disruptive behavior $(\mathrm{r}=0.583)$. Regression results also indicated students' disruptive behavior is the best predictor of teachers' job stress $(\beta=0.531)$. This finding goes along with other teacher stress related studies carried in other countries (Geving, 2007; Kyriacou \& Sutcliffe, 1978; Otero-López, Santiago, Godás, Castro, Villardefrancos \& Ponte, 2008; Grayson \& Alvarez, 2008; Evers, Tomic, \& Brouwers, 2004; Zedan, 2012).

The findings in this study also indicated that there is a positive moderate correlation between teachers stress and time pressure \& work overload $(\mathrm{r}=0.349)$. This is consistent with other studies (Kyriacou \& Sutcliffe, 1978; Kyriacou, 2001; Thomas, Clarke \& Lavery, 2003; Boyle, Borg, Falzon \& Baglioni, 1997; Pithers \& Soden, 1998; Abel \& Sewell, 1999; Kokkinos, 2007; Zedan, 2012; Kokkinos, Panayiotou, \& Davazoglou, 2005). However time pressure 
$\&$ work overload, though significant $(\beta=0.079, p<0.001)$ appears to be a weaker predictor of
teachers' stress at work compared to students' disruptive behavior.

Following the students' disruptive behavior, the relations with school principal appears to be the second significant predictor of teachers' job stress $(\beta=-0.241)$. This finding is confirmed by other results deriving from other stress related studies (Jackson, Schwab \& Schuler, 1986; Blase, Blase, \& Du, 2008; Grayson \& Alvarez, 2008).

On the contrary to some other study findings (O'Connor \& Clarke, 1990; Driscoll \& Beehr, 2000; Jarvis, 2002; Kokkinos 2007) this study proved that the relation with colleagues is not a significant predictor of teacher stress at work $(\beta=-0.080, p>0.05)$. Meanwhile this finding goes in line with the findings of Boyle, Borg, Falzon \& Baglioni (1997).

In this study are examined only four variables identified by the stress related studies conducted in other countries. Those variables explain $42 \%$ of the variance in the Albanian teachers level. This constitutes a limitation of the study. For explaining a larger amount of the variance in the teachers stress it is necessary to identify and examine a broader range of variables related to the teaching in the Albanian school context.

\section{Conclusions}

The aim of this study was to determine the impact of four variables (students' disruptive, time pressure \& workload, relations with colleagues and relations with school principal) on Albanian teachers' stress. The findings that the students' disruptive, time pressure \& workload and relations with school principal are significant predictors of teachers' job stress were consistent with the findings of the other studies on teacher stress carried out in different countries.

The conclusions of the present study are that changes are needed especially to the training of teachers and their workload. The extension of teacher's knowledge related to the student's age characteristics, in all levels of teaching with main focus on adolescent age and extension of skills and knowledge related to the management of deviant behavior in classroom would reduce the stress level of teachers. This can be achieved by giving more space and emphasis to the syllabus of developmental psychology and the classroom management in higher education which prepare future teachers, as well as by organizing in service teacher training on these topics. What could also reduce the amount of teachers' stress would be the identification and eradication of work overload sources and intervention for improvement in the system of school supervision, especially, with a focus on teacher support.

\section{References}

Antoniou, A. S., Polychroni, F., Vlachakis, A. N. (2006). Gender and age differences in occupational stress and professional burnout between primary and high-school teachers in Greece. Journal of Managerial Psychology, 21, 682-690.

Betoret, F. D. (2006). Stressors, self-efficacy, coping resources, and burnout among secondary school teachers in Spain. Educational Psychology, 26, 519-539.

Blase, J., Blase, J., \& Du, F. (2008). The mistreated teacher: A national study. Journal of educational Administration, 46 (3), 263-301.

Borg, M. G., Riding, R. J., \& Falzon, J. M. (1991). Stress in teaching: A study of occupational stress and its determinants, job satisfaction and career commitment among primary school teachers. Educational Psychology, 11, 59-75.

Boyle, G. J., Borg, M.G., Falzon, J. M., \& Baglioni, A. J. (1995). A structural model of the dimensions of teacher stress. British Journal of Educational Psychology, 65, 49-67. 
Stela KARAJ, Elida RAPTI. Teacher Job Stress in Albania: Examining the Role of Students' Classroom Disruptive Behavior and Other Factors in the School Context

PROBLEMS

OF EDUCATION

IN THE $21^{\text {st }}$ CENTURY Volume 54, 2013

Byrne, B. M. (1994). Burnout: Testing for the validity, replication, and invariance of causal structure across elementary, intermediate, and secondary teachers. American Educational Research Journal, 31, 645-643

Chaplain, R. P. (2001). Stress and Job Satisfaction among Primary Head teachers: A question of balance? Educational Management and Administration, 29 (2), 197-215.

Crank, J., Regoli, R., Hewitt, J., \& Culbertson, R. (1995). Institutional and organizational antecedents' of role stress, work alienation, and anomie among police executives. Criminal Justice and Behavior, $22,152-171$

Cronbach, L. J. (1951). Coefficient alpha and the internal structure of tests. Psychometric, 16 (3), $297-$ 334.

De Nobile, J. J., \& McCormick, J. (2007). Job Satisfaction and Occupational Stress in Catholic Primary Schools: Implications for School Leadership. Leading \& Managing, 13 (1), 31-48.

Dunham, J. (1992). Stress in teaching, 2nd Ed. London: Routledge.

Evers, W. J. G., Tomic, W., \& Brouwers, A. A. (2004). Burnout among teachers: Students' and teachers' perceptions compared. School Psychology International, 25, 131- 148.

Friedman, I. A. (1995). Student behavior patterns contributing to teacher burnout. Journal of Educational Research, 88, 281-289

Geving, A. M. (2007). Identifying the types of student and teacher behaviors associated with teacher stress. Teaching and Teacher Education: An International Journal of Research and Studies, 23 (5), 624-640.

Grayson, J. L., \& Alvarez, H. K. (2008). School climate factors relating to teacher burnout: A mediator model. Teaching and Teacher Education, 24, 1349-1363.

Guthrie, R. (2006). Teachers and Stress. Australia \& New Zealand Journal of Law \& Education, 11 (1), 5-18.

Ingersoll, R. M., \& Smith, T. M. (2003). The wrong solution to the teacher shortage. Educational Leadership, 60 (8), 30-33.

Jepson, E., \& Forrest, S. (2006). Individual Contributory Factors in Teacher Stress: The Role of Achievement Striving and Occupational Commitment. British Journal of Educational Psychology, 76, 183-197.

Jesus, S. N., \& Conboy, J. (2001). A stress management course to prevent teacher distress. The International Journal of Educational Management, 15 (3), 131-137.

Kokkinos, C. M., Panayiotou, G., \& Davazoglou, A. (2005). Correlates of teacher appraisals of students behaviors. Psychology in the Schools, 42, 79-89.

Kokkinos, C. M. (2007). Job stressors, personality and burnout in primary school teachers. British Journal of Educational Psychology, 77, 229-243.

Kyriacou, C., \& Chien, P. Y. (2004). Teacher stress in Taiwanese primary schools. Journal of Educational Enquiry, 5 (2), 86-104.

Kyriacou, C., \& Sutcliffe, J. (1978). Teacher stress: Prevalence, sources, and symptoms. British Journal of Educational Psychology, 48, 159-167.

Kyriacou, C. (2001). Teacher Stress: Directions for Future Research. Educational Review, 53,1, 7-35.

Lambert, R., \& McCarthy, C. (Eds). (2006). Understanding Teacher Stress in an Age of Accountability. Information Age Publishing, Inc.

Lazarus, R., \& Folkman, S. (1984). Stress, appraisal and coping. New York: Springer.

Manthei, R., \& Gilmore, A. (1996). Teacher Stress in Intermediate Schools. Educational Research, 38 (1), 3-19.

McCarthy, C. J., Lambert, R. G., O’Donnell, M., \& Melendres, L. T. (2009). The relation of elementary teachers' experience, stress, and coping resources to burnout symptoms. Elementary School Journal, 109 (3), 282-300.

McCormick, J. (1997). Occupational Stress of Teachers: Biographical Differences in a Large School System. Journal of Educational Administration, 35 (1), 18-38.

Munt, V. (2004). The Awful Truth: A Microhistory of Teacher Stress at Westwood High. British Journal of Sociology of Education, 25 (5), 578-591.

Nydegger, R. V. (2002). Stress and job satisfaction in white- and blue-collar workers. International Business and Research Journal, 1 (12), 35-44. 
O’Connor, P. R., \& Clarke, V. A. (1990). Determinants of Teacher Stress. Australian Journal of Education, 34 (1), 41-51.

O’Driscoll, M. P., \& Beehr, T. A. (2000). Moderating effects of perceived control and need for clarity on the relationship between role stressors and employee affective reactions. Journal of Social Psychology, 140, 151-159

Osipow, S. (1998). Occupational stress inventory professional manual (Rev. Ed.). Odessa, FL: Psychological Assessment Resources..

Otero-López, J. M., Santiago, M. J., Godás, A., Castro, C., Villardefrancos, E., \& Ponte, D. (2008). An integrative approach to burnout in secondary school teachers: examining the role of student disruptive behavior and disciplinary issues. International Journal of Psychology and Psychological Therapy, 8, 259-270.

Payne, M. A., \& Furnham, A. (1987). Dimensions of occupational stress in west Indian secondary school teachers. British Journal of Educational Psychology, 57, 141- 150.

Pithers, R. T., \& Soden, R. (1998). Scottish and Australian teacher stress and strain: a comparative study. British Journal of Educational Psychology, 68, 269-79. Publications.

Schwarzer, R., \& Hallum, S. (2008). Perceived teacher self efficacy as a predictor of job stress and burnout; mediation analysis. Applied Psychology : An International Review, 57, 152-171.

Skaalvik, E. M., \& Skaalvik, S. (2011). Teacher Job Satisfaction and Motivation to Leave the Teaching profession: Relations with School Context, Feeling of Belonging, and Emotional Exhaustion. Teaching and Teacher Education, 27 (6), 1029-1038.

Wiley, C. (2000). A synthesis of research on the causes, effects, and reduction strategies of teacher stress. Journal of Instructional Psychology, 27 (2), 80-87.

Wilson, V. (2002). Feeling the strain. An overview of the literature on teachers'stress. The SCRE Centre research in education. University of Glasgow.

Yamane, T. (1967). Statistics: An introductory analysis, $2^{\text {nd }}$ Ed., New York: Harper and Row.

Zedan, R. (2012). Stress and coping strategies among elementary schools teachers in Israel. Universal Journal of Education and General Studies, 1 (9), 265-278.

Advised by Zenel Orhani, University of Tirana, Albania

Received: April 09, 2013

Accepted: June 03, 2013

\begin{tabular}{l} 
OF EDUCATION \\
IN THE 21 $1^{\text {st }}$ CENTURY \\
Volume 54, 2013 \\
\hline 21
\end{tabular}

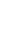

